Religion, Class, and the Postwar Development of the Dutch Welfare State 



\title{
Religion, Class, and the Postwar Development of the Dutch Welfare State
}

\author{
Dennie Oude Nijhuis
}


Cover illustration: Citizens collecting their old age benefits in the early 196os Source: Johan de Haas / International Institute of Social History

Cover design: Coördesign, Leiden

Typesetting: Crius Group, Hulshout

ISBN $\quad 9789462986411$

e-ISBN $\quad 9789048537648$ (pdf)

DOI $\quad 10.5117 / 9789462986411$

NUR $\quad 754$

(C) Dennie Oude Nijhuis / Amsterdam University Press B.V., Amsterdam 2018

All rights reserved. Without limiting the rights under copyright reserved above, no part of this book may be reproduced, stored in or introduced into a retrieval system, or transmitted, in any form or by any means (electronic, mechanical, photocopying, recording or otherwise) without the written permission of both the copyright owner and the author of the book. 